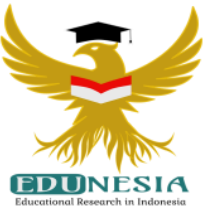

\title{
The Roles of Parents Teachers Association in School-Age Children's Psychosocial Development According to Erik Erikson
}

\author{
Sendi Wijaya \\ Magister of Education, Pelita Harapan University, Indonesia \\ Corresponding Email: Sendiwijaya@gmail.com, Phone Number: 0812 xxxx xxxx
}

\begin{abstract}
Article History:
Received: Nov 30, 2021

Revised: Dec 23, 2021

Accepted: Dec 28, 2021

Online First: Jan 01, 2022
\end{abstract}

\section{Keywords:}

Roles of parents and teachers, psychosocial development, Erik Erikson.

Kata Kunci:

Peran guru dan orang tua, Perkembangan Psikososial, Erik Erikson

\footnotetext{
How to cite:

Wijaya, S. (2022). The Roles of Parents Teachers Association in School-Age Children's Psychosocial Development According to Erik Erikson. Edunesia: Jurnal Ilmiah Pendidikan, 3 (1): 45-54.
}

This is an open access article under the $C C-B Y-N C$-ND license

\begin{abstract}
People these days tend to avoid their attention from child's psychosocial development while it holds serious role for the psyhcological and social development of children to find their true identity in the future. According to Erik Erikson, there are 8 stages of phsychosocial development of human starts when a human being is born to the final stage which is at 65 years old above. In this theory, Erikson emphasizes that every stage holds its importance and that they relate each other. Which means the first stage affects the next stage and so forth. This research is aimed to analyze Erikson's 8 stages development of psychosocial on school-age children and how parents and teachers should respond and provide suitable treatment for these children.The methodology in this research is literature research where author collects the information about 8 stages psychosocial development from journal, books, reviews, or previous research. From this research, author finds that parents must give proper and suitable parenting style for their child especially during their school periods where child needs support, motivation and stimulus either from parents or teachers or their surroundings through intensive communication. For addition, through this research too, author finds that the ability for teachers to understand these 8 stages will give them the sight to provide more chances for the children to grow well and find their true identity. From this research, we can conclude that either teachers and parents need to cooperatively work together to provides proper and suitable treatment for children's psychosocial development according to Erikson's 8 stages development.
\end{abstract}

Abstrak: Banyak orang yang tidak begitu memperhatikan perkembangan psikososial seorang anak terutama bagi anak-anak usia sekolah. Padahal perkembangan psikososial anak memegang peranan penting bagi anak tersebut di dalam menemukan jati dirinya di kemudian hari. Menurut Erik Erikson, terdapat 8 tahap perkembangan psikososial seorang individu dimulai dari ia dilahirkan sampai pada usia 65 ke atas di mana setiap tahap akan mempengaruhi tahap selanjutnya. Penelitian ini dilakukan bertujuan untuk menganalisis teori perkembangan psikososial menurut Erik Erikson pada usia anak sekolah dari kajian pustaka yang tentu saja relevan dalam pendidikan usia anak sekolah dan perlakuan yang perlu dilakukan baik oleh guru dan orang tua dalam perkembangan psikososial mereka. Metode penelitian yang dilakukan adalah kepustakaan yaitu dengan mengumpulkan informasi dari sumber-sumber terkait baik itu dari buku, jurnal penelitian ataupun penelitian terdahulu. Hasil dari penelitian ini menunjukkan bahwa orang tua perlu memberikan pola asuh yang tepat kepada anak mereka terutama di masa-masa usia sekolah di mana mereka membutuhkan dukungan dan motivasi serta stimulus dari orang tua melalui komunikasi yang rutin dan intens. Melalui penelitian ini juga ditemukan bahwa kemampuan guru dalam memahami perkembangan psikososial anak usia sekolah serta memfasilitasi anak agar dapat menemukan jati diri mereka sangatlah penting. Kesimpulan dari penelitian ini menunjukkan bahwa sejatinya baik guru dan orang tua harus bersinergi dalam memberikan perlakuan yang seimbang dan sesuai dengan teori perkembangan psikososial yang dikemukakan oleh Erik Erikson. 


\section{A. Introduction}

Education is an important factor that holds serious role in the process of changing from a human being. The theories of education are widely discussed and stated by philosophers such as John Dewey, J.J Rousseau, St. Augustine and many more. John Dewey stated that education is the process where essential skills are shaped and established emotionally and intellectually while Rousseau said that education is a process where human beings get what they need in the future. Truthfully, the characteristics of education is practical, normative and must be based on the theory itself. Through the education, someone learn how to become a good human being. This emphasizes the education as a process that needs human efforts to show the changes in their lives and that the changes must be able to be indicated by measurement. In education, learning is the main component, learning has various aspects that connect each other and holds important roles in the development of psychology and psychosocial of a child. Although sounds similar, but actually either psychology and psychosocial have different meaning and intention. According to Uba Umbara in "Psikologi Pembelajaran Matematika" psychology is defined as a study which learns about the condition of someone mentally and emotionally (Umbara, 2017).

There are many theories that define psychology and its function. Along with its development, psychology does not only study about the certain condition of human mentally and emotionally, but also expands its meaning to a wider state which is called as psychosocial. Psychosocial is the fussion of two different words Psychology and social. According to Erik Erikson, psychosocial refers to a condition where there is interconnection between someone's psychological and social condition and that they affect each other. In addition, Erikson states that there are 8 stages in psychosocial development (Erikson, 2012). This 8-stages then stated in his book that discussed about the development of child's psychosocial development in every stage and how each of the stage is affected by other stages in order to help a child to find his / her own true identity in the future. This result of research was based on Erik himself experiences where he once has ever been through difficulty to find his own true identity caused by the ignorance from his step father. Thus, Erikson then said that when a child is in a certain stage of his / her psychosocial development, then whatever treatment he / she receives from the surroundings will affect what this child will become in the future this child's characters development. This developmental character surely goes through a process where social interaction in the environment which involves parents, teachers, friends and their surroundings will give impact in shaping the characters of each child. It is surely said that a child that goes through a positive environment will be able to develop positive characters inside him/herself (Zubaedi, 2017).

After 13 years dedication as a teacher, author does reflection to really understand what is education and also what's inside in the education and what is actually the character of the education these days. A lot of questions come to surface as author finds many cases where the victim of these cases always the children. The parents are too busy to at least provide one hour intensive talks with their child (Mc.Wyne, C. Elliot. 2013) or parents who always 
think that they have given the best for their child while they are not. There are a lot of parents who missed their child school age periods as they spend more time outside then they treat their child wrongly (Torres \& Manuella, 2014). If this happen, it is better if parents treat their child according to theoretical treatments so that every treatment that is given to children, it can match the needs of every child and suitable for the children's psychosocial development. Then the big question is whether parents and teachers know how to treat these children during their school-age periods along with the psychosocial developmental? This research explains how parents and teachers can treat these children properly based on the 8-stages psychosocial development according to Erikson's psychosocial development stages. Erikson states that it is crucial for parents either mom and dad to know these stages, this encourage them and enhance them to understand their child better so that they know how to treat them wisely and properly because when they can do this, Erikson says that there will be no children lose their identity. These children will grow with good social skills, manners and able to find their true identity with ease. Through this research, author emphasize the discussion on the phase of school-age children which scoops 6-12 years old children where Erikson believe that these stages are very crucial for them to decide what they want to be in the future. In this stage also, teacher and parents hold super important roles to educate their child or students to get well treated during their school-age phase.

\section{B. Method}

The methodology used in this research is literature research. Literature research refers to a research which in the process of the research author uses various of sources to collect data such as books, journals, articles or previous research (Hasan, 2008). This technique or methodology requires the author to read more books or article journals that are related to the research being done. This methodology is usually used to strengthen or emphasize data or facts and compare the differences and similarity from those various sources author has collected (Kartono, 1998).According to Kartono (1998) there are four main characteristics of literature study or research, first is that the author must read ready-used books or texts directly without any intermediaries, the sources can be secondary sources and not main sources, and the last one is that this research is not limited by time and space like other research (Zed, 2008).

\section{Result and Discussion}

\section{Biography}

Erik Erikson was born on 1902 in German and raised during the second World War 2. Since he was born, he never knew who was his biological father while his mom got married for the second time with a doctor named Homburger who ws also a Germany (Mac Lean \& Syed, 2015). Since little kid, Erik often felt lonely and never got proper affections from his step father who always treated him differently with his step little brother. This made little Erik felt anxious inside him and because of that, little Erik got problem during the discovery 
of his true identity. On 1927, Erikson then joined an institution which established by Sigmund Freud, a psychoanalysis who well-known and famous that time. There, he met a beautiful lady named Joan Serson, a Germany woman who would then marry Erikson on 1929 (Alini \& Indrawati, 2020). Erikson then discovered 8 stages of psychosocial development. After his biggest discovery, Erikson still continued his research until then found died on 1994. During his life, he contributed in many ways especially in education. He wrote many books and articles that contributes education and psychology until this day.

\section{Theoretical of 8 Stages Psychosocial Development}

As quoted in Humans Life Cycle and their Identity (1989), Erik Erikson succeeded to discover this theory that began by the messed up in his life; his family background, education and his profession to the final hard phase in his life which made him struggle to find his true identity. Through this discovery, Erikson wanted to speak what's on his mind about how whatever happens in the past of someone's life, will affect an individual's character building in the future. This also includes the ability of an individual to adapt and socialize in the future. Before the further discussion about what are the 8 stages that discovered by Erikson, we need to know first, what is psychosocial. Psychosocial refers to the interpersonal connection which is affected by psychology factor. This means, either psychology and social condition affects each other. Erikson stated that there is connection in the development of psychosocial that involves the growth of ego that exists in an individual. Erikson added that this ego will keeps going as long as the experiences and information that someone has also increases in terms of quality and quantity so that the development of psychosocial that someone has will always be affected by what happens in his life. If a child gets a positive experience and information from his surroundings, then there will be a positive psychosocial development withing the child, but the opposite outcome happens, it the negative ones that this child gets. Erikson split the stages of psychosocial development into 8 steps. The first stage begins within $0-2$ years age of child, in this stage, a child begins to have a permission for himself to trust his surroundings to fulfill his needs (Snarey, 2011). The roles of parents in parenting and taking care of this child or choosing a suitable baby sitter will holds an important and significant job. This stage allow the child to expects that his needs such as food, drinks, loves, warms, and cares can be fulfilled by parents. Not only by parents but also buy the surroundings. This can build trust within the child that his surrounding cares for him and that he can trust back (Gilleard, 2020). However, if the opposite thing happens, this child will not be able to trust the surrounding and build a view that his surrounding is a place that he does not want at all.

Second stage begins from years 2-3 of age. This stage is also called as autonomy vs shame and doubt. In this stage a child starts to develop the ability of confidence which can be done by starting by doing simple things by themselves such as wearing clothes, walking, talking, moving, wearing diapers, and most importantly getting answers of their questions properly If they don't get this, things that will happen such as lacks of trust and confidence. 
The roles of parents and people in their surroundings such as giving motivation and support their child to keep on trying and show more efforts is really important in this stage.

The third stage begins from years 3-6 of age. In this stage a child begins to test some abilities that they think they can do it already. They do this in an assumption that they have it without knowing their truly potential. In this stage, a child tends to do mistakes while they develop the initiative. That is why in this stage, they really need their surroundings to stay on saying positive things yet supportive that can build their confidence. If they don't get proper things in this stage for example, instead of getting positive and supportive words from surroundings, they get negative words that can make them sad and not confidence, or even worst they get anger and abusive words from their parents, this will make the children grow to become a child that always feel guilty in their life. And of course, this thing would not happen to children who always get supportive words from their surroundings.

The fourth stage begins from 6-12 years of age. In this stage, child begins to meet people who have same age with them in the environment and schools. In this stage, they will start to compare themselves with their friends from the perspective of what they have and what they can do. The competitive characters will be developed in this stage academically or socially among their friends. When a child finds his own success in this stage, this will develop his own confidence and trust about himself. But when they find failure, they tend to become inferiority and to anticipate this feeling, either parents or teachers should motivate them and keep on support them give them positive and supportive words to give them their confidence back so that they want to get back on their feet and try again to be better. If they get the opposite thing, then they will have lack of confidence and always think that they are weaker than their friends in any aspects (Samsanovich, 2021).

The fifth stage begins from 12-20 years of age, here a human begins to know themselves. They start to recognize their identity from simple things. There will be many struggles within themselves in this period, so that parents' teachers' roles are really important. They need guidance both from teachers and parents. If they get proper guidance, they will find their identity with ease. But if they don't get guidance and support system from parents and teachers, they will not know their true potential and there will be bias within themselves. This will make them don't understand about themselves and that they cannot find balance within themselves as well.

The sixth stage begins from 20-40 years of age. In this age, parents or teacher are no longer having the biggest role but their loves, husbands, wives etc who have intimacy relationship with them. If they get what they need in this stage such as loves, warmth, and supports, they will become a happy person, but if the opposite things happen, they will not be able to find happiness in their life.

The seventh stage is started from 40-65 years of age. This stage is also called as generative vs stagnancy, which means the success in educating and parenting their child, family and works will give effects in the form of cares. But if they don't, then stagnancy will be developed for the rest of their life. 
The last stage starts from 65 years of age - the death. Conflict happens in this stage are integrity and despair. The experiences that happened in their life will become the main factor wither despair is developed or not for the rest of their life. In this stage, people need someone to go through that despair.

\section{Discussion}

After knowing every stage of psychosocial development stated by Erikson, we can understand that for people to go to the next stage they will have to finish the previous stage properly they need to have proper treatments. Butt he reality does not always go that way. There are many children in the world that don't get loves that they deserve so that they can go the next stage well. According to WHO in 2020, there are many children in the world get abused by their surroundings. They reported that $88 \%$ from 190 country become a victim of abusive which are sexual harassment and verbal harassments. Sadly this abusive action is done by their closest relatives such as parents, teachers, uncles etc. These children don't get love, motivation, needs which they should get during this stage for their psychosocial development (Livana, M.Ramli, \& R, 2021). In 2008, there was a child in author's classroom. This child is 10 years of age and was in grade 4 that time. This child is a slow learner and lack of academic skills and confidence. This child was weak at almost all subjects. After observation, author did some treatments to this child which is shown in the diagram below:

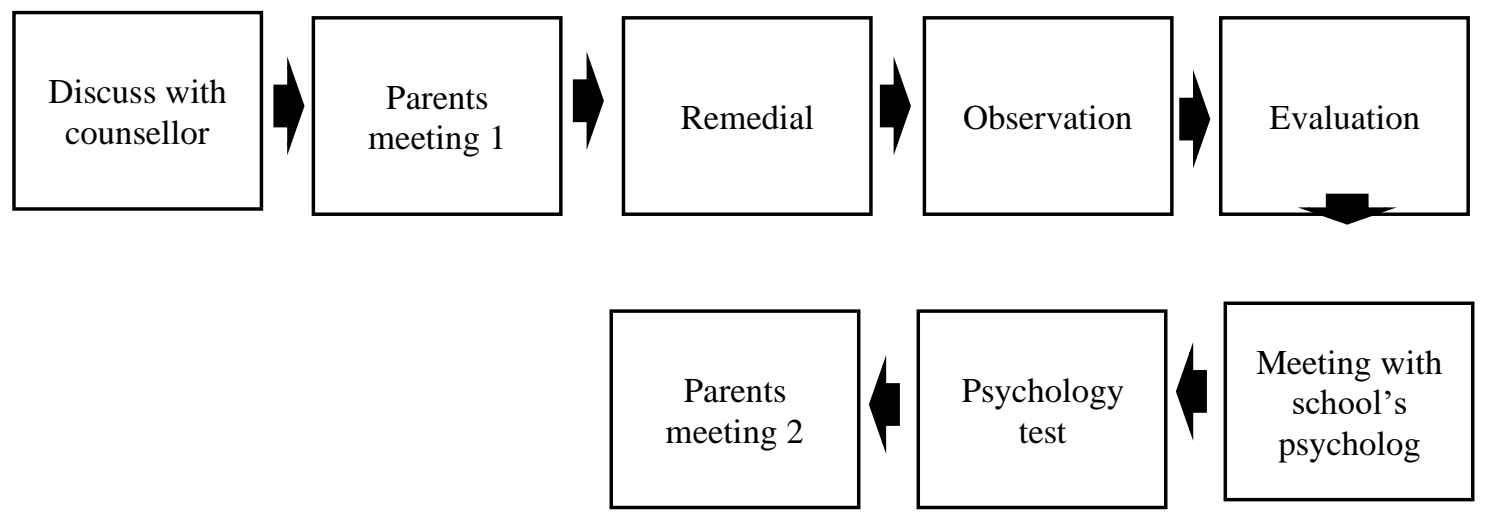

Figure 1. Treatment steps

Explanation:

1. Discuss with a counsellor, in this step, author created a dialogue with school's counsellor about the problems with this child and his resumes in previous classroom. After that we dealt to invite his parents for a meeting.

2. During the parents meeting, this child's parents a little bit introvert, they did not share much information that can help us teachers and school to analyze more about what happens with this child. But for sure, this child's parents were super busy and they admitted that they did not have much time with their child for study or small talks. At the end of the meeting, teacher gave a solution to provide extra guidance academically for this child. 
3. Additional lesson or remedial was held twice a week, teacher did various teaching strategies then observed.

4. After observation, author then did an evaluation to what has worked and what has not worked yet.

5. Since the evaluation has done, author then brought the result of evaluation and observation to the school's psychologist and had a dialogue.

6. School's psychologist suggested to give a series of test to this child with parent's agreement.

7. We then discussed the test result with this child's parents on the second meeting.

On the second meeting, author, psychologist, and this child's parents talked with a heart-to-heart condition by showing them the result of the test. The test showed that there were some treatments which they should have given in the stages of psychosocial development of this child but they did not because of the business they had. During this meeting, parents more open to the story of this child during the age of 3 . They were too busy to give time or affection to this child and this child got some bad treatments for his nanny and this child's parents were also too busy to have a small discussion with this child. Parents were to tired to answer simple questions from this child. Refers to this case, we can see that Theoretically, what Erik Erikson stated in his 8 stages psychosocial development is valid. This child did not complete the second and third stage well. So that the outcome was not expected as well. Through these two stages as explained before, are the stages where a child builds their trust and confidence within themselves by showing their surroundings that they can do things independently and developing their initiative. In these two stages, parents should give more time to support their own child by giving them motivation and chances to be more confidence (Samsanovich, 2021). But if this thing could not happen, then unexpected outcome will come to the surface; child become inactive, lacks of confidence, they don't trust their surroundings, and their psychosocial is also distracted as stated by Erikson that every stage affects each other so that what happens in the previous stage will give impact to the next stage of child's psychosocial development (Kivnic, 2014). The second case happened this year, during pandemic, and this time we, teachers, counsellor, and psychologist did the same series of treatments to this child. The result was not expected at all, this child's parents often scold this kid with abusive and negative words. During the treatments, this kid told us that she wanted to study at school and even did not want to study with her parents anymore. Although a little bit different with the first case, but still, negative treatments received by this kid so that the output was not as expected. This kid lost her confidence and motivation to study (Utami, Muslima, Putri, \& Lia, 2020).

a. Through these two cases we can conclude that the roles of parents in parenting and educating their child is very important. And the ability for teacher to give motivation and provide well treatments for kids also holds a big role. According to Evelyn (2003), in the Marriage and Family Development there are three parenting style that can affect child's psychosocial development: permissive, authoritarian, and democracy (Suryanto, 2019). Authoritarian, is a parenting style that has stiff and strict characteristic. Other than 
that, this style allows punishment as part of the parenting at home. Parents are so strict and often giving orders to their kids. The relationship more likely military style. They order everything that their child must do. A child that is educated with this style tends to have lacks of confidence and they don't trust to themselves or even worse to their surroundings. In addition, the output can also put them to become a sad, moody and careless child.

b. Democracy parenting style, this style is the most ideal style of parenting these days. Rules are often made and agreed together at home among the members of the family. Not only that, parents who apply this style at home also always tell their child why is something wrong so that their child know what is wrong and what is correct. They know the reason behind their mistakes. The outcome from this parenting style such as the kids become more confident, they have good psychosocial and more mature and also able to adapt or socialize easily with their surroundings.

c. Permissive parenting style, in a family who have this style, accidentally or not, we can see that they give too much freedom for their kids to take care of themselves. Parents give equal portion in taking decisions at home so that there will be imbalance and the kids will have lacks of guidance while school-age child still needs guidance in taking decisions and taking care of themselves to make them more trust to everything happen in their life and the decision they take. If this style keeps happening in a family, then the child will have low self-control and confidence. (Kupens \& Ceulemans, 2019).

The development of parenting style becomes a very basic yet important for the psychosocial development of a child. Even so, teachers also hold a big role at school that they must do because it is very important for teachers and parents to work together and silmutaneously for child's development (Krismawat, 2014). The roles of teachers as stated in the law number 20, chapter 40 verse 2 is written as shown below.

- Create a fun, meaningful, creative and dynamic learning.

- Have commitment professionally.

- Become a role model and inspiration for kids and institution.

Other than what are written above, according to Wrightman in Uzman Uzer (2002) teacher's role also includes creating a series of activities that are related for the improvements and development of attitude towards kids. According to G. Beider in Kompri (2015:31) teachers' roles in developing child's attitude are listed below:

- Teacher must have positive mind towards their students.

- Teacher must have strong will to always study to achieve goals in their students' education.

- Teacher must have mindset that the job for teacher is not only teaching but also paying attention to their students changes of attitude and development.

- Teacher must give positive motivation to their students.

According to the explanation above, we can conclude that the job for teachers is not only teaching, but also observe their students' change in behavior so that their psychosocial development can be fulfilled well in every stage. 


\section{Conclusion}

From the discussion above we can conclude that the development of psychosocial of every child especially in school-ages student needs more attention either from parents, teachers and institutions. And this can be happened by showing and giving them proper treatment and parenting style that match with the 8 stages psychosocial development stated by Erikson. This because we have understood that every stage affects each other so that if a child does not pass through a certain stage well, then he/she will not be able to complete the next stage well, and if this happens, then this child will have lacks of confidence, learning motivation, disbelieve to his/her own surroundings and more over they don't have self believe. Author suggester for parents and teachers to understand every stage of psychosocial development so that they know what are the proper treatments for every child such as give more positive motivation, warmth, loves, and cares either in family or schools. Teachers can give guidance for their students which probably has passed these stages not as good as other students by giving them some more chances and motivation in the classroom during the lesson or outside the classroom.

\section{References}

Alini, \& Indrawati. (2020). Hubungan Tingkat Pendidikan Dan Tipe Pola Asuh Orang Tua Terhadap Perkembangan Psikososial Anak Usia Prasekolah. Journal NERS Universitas Pahlawan, 110-115.

Erikson, E. (1989). Identitas dan Silus Hidup Manusia. Jakarta: Gramedia.

Erikson, E. (2010). Teori Perkembangan Psikososial Erik Erikson. Jakarta: Gramedia.

Erikson, E. (2012). Teori Perkembangan Psikososial . Jakarta: Gramedia.

Gilleard, C. (2020). The Final Stage f Human Development? Erikson's View and Integrity and Old Age. International Journal of Ageing and Later Life , 1-24.

Hasan, I. (2008). Analisis Penelitian Dengan Statistik. Jakarta: Bumi Aksara.

Kartono, K. (1998). Pengantar Metodologi Research. Bandung: ALUMNI.

Kivnic, H. C. (2014). Untapped Richness in Erik Erikson's Rootstock . The Journal Gerontologist Series, 40-50.

Kompri. (2015). Motivasi Pembelajaran Perspektif Guru dan Siswa. Bandung: PT. Remaja Rosdakarya.

Krismawat, Y. (2014). Teori Psikologi Perkembangan Erik H. Erikson dan Manfaatnya Bagi Tugas Pendidikan Kristen Dewasa Ini. KURIOS; Jurnal Teologi dan Pendidikan Agama Kristen, 44-56. 
Livana, M.Ramli, \& R, C. L. (2021). Adakah Hubungan Kekerasan Fisik Dan Verbal Orangtua Dengan Perkembangan Psikososial Anak Usia Sekolah? Jurnal Ilmu Keperawatan Jiwa, 201-214.

Mac Lean, K., \& Syed, M. (2015). The Oxford handbook of identity development. New York: Oxford University Press.

Mc.Wyne, \& Elliot, C. (2013). Father Involvement During Early Childhood and Its Association with Children's Early Learning: A Meta-Analysis. . Early Education and Development Journal, 898-922.

Mokalu, V. R., \& Boangmanalu, C. V. (2021). Teori Psikososial Erik Erikson: Implikasinya Bagi Pendidikan Agama Kristen Di Sekolah. Vox Edukasi: Jurnal Ilmiah Ilmu Pendidikan, 180-192.

Samsanovich, A. (2021). Theory And Diversity: A Descriptive Study Of Erikson's Psychosoci Chosocial Devel Al Development Stages. California State University San Bernadino, 1-34.

Snarey, P. J. (2011). Encyclopedia of Child and Development Behavior: Erikson's stages of the Life Cycle. Boston: Springer.

Suryanto. (2019). Sosiologi Anak. jakarta: Prenada Media Group.

Torres, N., Manuela, \& Eiro, L. (2014). Father Involvement, Social Competence and Problem Behavior in Preschiil Children. Journal of Family Studies, 188-203.

Umbara, U. (2017). Psikologi Pembelajaran Matematika. Yogyakarta: CV Budi Utama.

Usman, U. (2002). Menjadi Guru Profesional. Bandung: PT. Remaja Rosda Karya.

Utami, W., Muslima, E., Putri, I., \& Lia, N. (2020). Perkembangan Psikososial Anak Jalanan Pada Remaja Di Kabupaten Bojonegoro. Stikes Rajekwesi Bojonegoro, 1-6.

Zed, M. (2008). Metode Penelitian Kepustakaan. Jakarta: Yayasan Obor Indonesia.

Zubaedi. (2017). Strategis Taktis Pendidikan Karakter. Jakarta : Raja Grafindo Persada. 